\title{
THE CAUSES OF THE FRENCH REVOLUTION
}

(By The Very Rev. Can. Prof. A. Bonnici, B.A., B.L.CAN., D.D., H.E.L.)

F we were to expose and discuss what the several historians had written about the causes of the French Revolution, the time of a lecture or the space of an article would not be sufficient. It is for this reason that we are going to leave apart all the particular views of the authors singularly taken and contenting ourselves of the short bibliography mentioned in the foot-note(1), we intend classifying the causes which they mention into categories, viz :

1. Social causes: class interest and social distinction;

2. Administrative and Juridical causes: faulty administrative system, and confusion of courts and laws;

3. Religious causes: Protestantism, Gallican theories and Jansenistic opposition ;

4. Philosophic and Anarchic causes: Illuministic movement and Masonic propaganda;

5. Political causes: King's weakness and appalling financial plight;

6. Constitutional causes: all-pervading idea of the people's sovereignty and the desire for a change in the form of government.

(1) BIBLIOGRAPHY :

Cambridge Modern History, Vol. VIII, Cambridge University Piess, 1934.

De Tocqueville Alexis: L'ancién Régime et la Révolution, Payis, 1856.

Taine Hippolyte: Les origines de la France Contemporaine, 6 Vols., Paris, 1876.

Sorel Albert: L'Europe et la Révolution, Paris, 1864.

Madelin Louis: La Révolution.

Aulard A.: Etudes et leçons sur la Révolution Française. Paris 1902.

Carlyle Thomas: The French Revolution, 3 Vols., London, 1913.

Belloc Hilaire: The French Revolution, Home Univ. Libr., 1915.

Mathiez Albert: La Révolution et l'Eglise, Paris $190 \%$.

Sicard Augustine: L'Ancien Clergé de France, Paris, 1903-1905.

De la Gorce Pierre: Histoire religieuse de la Révolution.

The Historians' History of the World, Yol. XII (France 1715-1815). 


\section{I-CLASS INTERESTS AND SOCIAL DISTINCTIONS}

There existed in France before the Revolution a population of 25,000,000 souls, divided into three Orders or Classes called "Etats" ("Estates") : the I Estate comprising the Clergy, the II Estate or the Nobles, the III Estate including the people. These three classes had relative positions and conflicting interests, as we shall briefly describe in order to better understand the course which each of these Orders took in the Revolution. and the character and eflects of the Revolution itself.

\section{A-The Clergy.}

The Clergy of France was a potent factor in the government of that nation. It still retained, outwardly at least, the same, or almost the same position of the Middle Ages. The number of the Clergy - secular and regular - at the time of the Revolution amounted to 93,000 (2). They enjoyed a real, though limited, power of self-government through their provincial and national assemblies. The latter were summoned every five years by the King and contained four representatives of each of the 16 Provincial Assemblies, two of whom were bishops and two of the inferior clergy. This prerogative was, however, being limited, from time to time, by the Crown. Since the agreement between Pope Leo X and Francis I (1516), the King was given the inght to nominate bishops and archbishops, subject to papal confirmation, and to fill up a great number of wealthy abbacies, and to confer several other minor preferments. Thus the clergy was becoming, under a certain aspect, dependent to the King; and, since the big benefices were reserved for persons of gentle birth, the King was thus enabled to control together with the Clergy, a considerable part of the Nobility.

From the above-said one can easily understand that the French Clergy was divided into two categories: the superior and the inferior Clergy. The Higher Clergy taken in gross, were courtiers and men of the world; the Lower Clergy were persons mostly drawn from a humble middle class, or even from the peasantry, poor, uncultured and unpolished. Though some of the higher clergy were dissolute and incredulous, others there were of sterling piety and benevolence, and the majority ob-

(2) Taine H. op. cit.-Of these 70,000 composed the secular clergy, and 28,000 the regular clergy. The number of nuns was 37,000. This brings the ratio of 6 priests, 2 monks and 3 nuns to every 2,200 souls. 
served outward decorum. Among the lower clergy there appeared now and again men of wide culture; and almost all this class was regular and edifying in their lives.

The scandal among the clergy was the distribution of ecclesiastical revenues. Those who did most work were, as a rule, the less rewarded. The Archbishops, Bishops and prelates received lucrative benefices; while parish priests were shamefully ill-paid; so that in 1768 and 1786, the State had to intervene and enforce a minimum stipend (portion congrue) which was to be given them by the bishop: other uncertain dues (casuel) were paid by the people, and consequently regarded as grievances by the latter.

Beside this social division of the Clergy, there was the canonical division of the secular and the regular clergy.

Having al:eady spoken about the secular clergy, we add a few words about the regular: This clergy had been losing its ascetic enthusiasm; and, although the religious houses were still numerous and wealthy, their number, however, was considerably decreasing. The regular clergy was disliked by the peasants, ridiculed by men of letters, and considered useless and encumbrous by statesmen.

The moral influence of the clergy in France was waning. Although the clergy, nuns included, were almost the only teachers oi youth, and although the Catholic Religion was the only otticial Relicion of the State, and its worship was the only worship publicry allowed, the moral influence of the clergy was waning and the public tolerant opinion was rapidly gaining ground and awaking general disgust among the laity (3).

\section{B-The Nobility}

The French Nobility correspond to the English Nobility together with the English gentry. According to Taine, at the ave of the Revolution, there were in France 140,000 noblemen i.e., more than 5 to every 1,000 inhabitants. Nobility was acquired either by birth, or by the power of the Crown, or by the purchase of one of about 4,000 civil offices. The French Nobility as a whole was not rich: the majority owned very little land and drew nearly all the income from the so-called "seigniorial" rights, which were often ill-defined and burdensome, and

(3) Montague F.C.: The Government of France (in Cambridge Moderu History, Vol. VIII, pp. 52-56). 
consequently source of litigation and unpopularity. In order to cope with the expenses of life, these poor noblemen were often compelled either to join the Army or the Navy, with small hopes of promotion, because of the intrigues and favours, or to marry a wealthy woman of the lower class, in spite of the prejudice then existing against such marriages.

The Noblesse as a class had no political power; but they enjoyed several privileges, such as exemptions from the bulk of the direct taxes, a monopoly of field sports and an enervated feudal jurisdiction. The King, the Nobles that surrounded him - the so-called Nobility of the robe - and the Crown officials wished to gratify these noble fellows of theirs - the Nobility of the sword - but so far as was compatible with their desire for absolute power : because it was for the gain of this absolute power that they had been sapping the power of the noblesse; and had at length reduced it to a political nullity.

Under so deadening conditions, any political capacity in these members had withered; while their privileges and exemptions still served to wound the pride and self-interest of the other classes (4).

\section{C-The Third Estate}

All the remaining part of the population formed the so-called "Third Estate" or "Tiers Etat". 'This Order comprised the Middle Class and the Peasantry.

The Middle Class

But for some exceptions, there were in France before the Revolution no tenant-farmers, or better, these tenants had so little as not to rise above the degree of a peasant. Consequently the French Middle Class was urban - "bourgoisie" in the proper sense of the term. It was composed of citizens belonging to the governirent bodies or to any of the professional corpoiations, who, with the purchase of an office, obtained the privileges and the dignity of servants of the Crown, and made friends and connextions that raised them in importance.

This class had been steadily increasing in wealth and in number. Apart from their legal privileges, they received very cheap, and sometimes gratuitous, education, they were generally free from militia service: Nearly all lucrative employments were

(4) Montague F.C.: op. cit. pp. 57-59. 
filled by these citizens. This class supplied the great majority of lawyers, judges and civil servants, the contractors who reaped a rich harvest in every year, and the financiers who farmed (5) the indirect taxes. If the bourgoisie had little land, they however possessed nearly all the capital of France, held the bulk of the public securities, and counted many a noble and prelate among their debtors. Every year they became a greater force in the kingdom. "With' a few exceptions, Montague says, the leaders of the French-Revolution in every period of its history came from this class (6).

\section{The Peasantry.}

In spite of the prosperity and wealth of the bourgoisie, France was eminently an agricultural country : four-fifths of the population $(20,000,000$ souls) were employed in tilling the earth. As we have said, only few tenant-farmers formed part of the Middle Class; nearly all the agricultural population were peasants a population that outnumbered all the other classes put together. The bulk of the peasantry had achieved personal freedom from the feudal villenage and they had acquired an immense interest in the land.

The condition of the French peasantry was three-fold. i.e., the hired labourer, the metayer and the petty proprietor.

The hired labourer held and worked his district paying a rent to the owner. His land was among the best tilled: and he was substantial.

The metayer, held by lease the land of the Crown, clergy or nobles. He was furnished by the lord of a variable proportion of the capital required, and gave to the lord a variable proportion of the gross produce.

The petty proprietor cultivated a small estate, but his own.

The peasantry as a whole fretted under the several manorial rights of which we cannot say the amount in proportion to the gross value of the peasants' land. These impositions started to be regarded as intolerable to the peasants, especially, when, with the lapse of time, they started to consider themselves as the owners and not the tenants of the land.

(5) To farm an indirect tax means to pay a lump sum of money to the Government and receive from it the right of collecting the tax for yourself.

(6) Montague F.C.: op, cit., p. 61. 
It was the districts full of metayers and petty owners that rose up against the seigneurs, and broke up into anarchy in the first months following the meeting of the States General.

But it is not right to insist upon the miserable state of this class as the sole cause of the Revolution (7).

\section{D-The Army.}

In order to mention all classes and ranks of the French people, it would not be out of place to say something about the French Army.

The French Regular Army, in comparison with the armies of other nations (say of Prussia), was rather small. At the time the Revolution broke out, it numbered approximately 160,000 soldiers, one-sixth of whom were foreigners - a thing common at that time. In this Army discipline and skill were valued more than numbers.

Two factors used to work in the enrolment of soldiers : first, the powerful tradition of the age of chivalry, namely, that arms are the true profession of a gentleman. and this disposed the nobles, especially the needy ones, to accept commissions as officers in their country or in any other christian army; secondly, the need which forced the very poor, the thriftless and the dissolute to join the army in order to earn their living.

The man of the Middle-Class could not easily become an officer. he would not be a soldier, and consequently almost no one of this class was in the Army.

As matters stood. the Army contained a number of officers ont of all proportion to the privates. At the time of which we are speaking there were 966 generals. 1918 staff officers in the French Armv i.e. 1 general to every 2 officers and to every 157 privates. Influential persons obtained commissions at an early a.ge (sometimes at 16 years). Bad fare and hard usage made desertion common with a detriment to the Army, that was losing its military fame.

"Yet. Montague writes, that there was excellent stuff in the roval army was proved by the number, both of privates and of officers who rose to fame in the wars of the Republic and the Fimpire. Out of 24 marshals of France created by Nanoleon, 8 had been officers and 10 had been privates under Louis XVT".

(7) Montague F.C.: op. cit. pp. 59-65. 
Beside the Army, there was the Militia of about 60,000 men. This force was raised by a sort of conscription. 10,000 soldiers were recruited yearly for six years service. The exemptions were so widely extended that only the poorest class of peasants were recruited. These exemptions from military service caused another source of discontent in the lower class (8).

\section{II-FAULTY ADMINISTRATIVE SYSTEM AND CONFUSION OF COURTS AND LAWS}

The French Adminstrative System before the Revolution was grieviously faulty.

The King was the only master of France. But in order to rule over such a great civilised community of 25 million souls, he concentrated all the business on a Council. This Royal Council, at the eve of the Revolution, numbered 40 members, comprising the Ministers and a much larger number of members without portiolio. The most influential of the Ministers and members was the Controller-General of the Finances, who might exercise the authority of a Premier. The Ministers were often Nobles or Prelates. The other members, as a rule were from the Middle Class, who brought with them the advantages of long: experience and administrative dexterity. The Council donstantly reviewred the administration of the whole kingdom, from drafting new laws to the repair of a parsonage. The Council exercised also an unlimited judicial power, there being in France at the time no Supreme Court of Appeal.

France was then divided into 30 Provinces or "généralités", each led by an Intendant, as a rule not of noble birth, helped by a Chamber of fiscal officers known as "généraux des finances". Each "généralités" was subdivided into districts called "élections".

For the maintenance of order the Intendant had at his disposal the rural police, and could even dispose of the municipal nolice force. He had also a summary jurisdiction to repress disorders and could sentence even to death. He was in charge of public. work, of exaction of taxes, of relief to the poor, and of improvement of industry and commerce. Though, insensibly, this class of civil servants had started to exercise a uniform movement of the bureaucratic machine., Only few Provinces

(8) Montague F.C.: op. cit. pp. 51-52. 
known as "Pays d'Etat" had retained the right of self-government, but this was in some cases nominal, in other very restricted. They had no legislative power, being only administrative bodies: and in many details were milder and more reasonable. In these "Pays d'Etat", three orders represented the population : viz: the I, II and III Estates. But the representation was not always fair. Sometimes one or the other of the orders was not proportionally represented, and besides, the peasant class was not represented at all : this explains why there was no murmur from the Provinces, when, in 1789 , the peasantry was excluded from the National Assembly.

The Communal and the Municipal institutions and their respective systems had been preserved by the Crown and the Ministers, but all their actions were supervised by the Intendants, and the work of these was to be reviewed by the Council. The scope of this preservation was to have an instrument which could be useful and could not be dangerous. But the King and the Ministers forgot that even the humblest form of self-government must be attractive before it can be efficient.

The domineering authority of the Intendants and of the Council must have discouraged municipal patriotism, weakened the exercise of original talent, enervated private enterprises, voluntary association and municipal energy: while the detailed supervision of the Crown and of its agents required an army of civil servants, and there being more than 40,000 communes in France, the communal business was always in arrear.

And nobody could criticize this system! Criticism of the government was at the peril of the critic: it was only limited to speculative questions. Even the financial state was almost unknown to the people. This secrecy compromised the Government and sometimes made it accountable for crimes it had never committed, which became the daily food of an ignorant, suspicous and suffering people (9).

Another flaw in the French Institutions was its Judicial system. It had been gradually formed since the Middle Ages, and it had never been revised on broad principles, and accommodated to time and circumstances, and consequently it ended in exceptional confusion and waste of power. In the Middle Ages every lord, every chartered town, every ecclesiastical diocese had

(9) Montague F.C.: op. cit. pp. 36-45. 
its own Court. Feudal, corporate and ecclesiastical competition left little to be done by the Royal Court. Duty and interest impelled the King of France to enlarge progressively this jurisdiction, but unfortunately, as the substance of power increased, its reforming energy expired.

The Royal Courts were of three degrees:-

i) 'The "Parlements", 13 in number, were Courts of the highest rank, from whose decision there was no appeal. Among these, the most ancient, the most illustrious and the most powerful was that of Paris, whose jurisdiction extended over a great part of the Kingdom and perhaps 10,000,000 human being. It will be useful to add, lor a better understanding of what we shall say later on, that these "parlements" deemed themselves more than judicial bodies, because their function of registering the royal edicts macle them assume the right of criticizing and even of vetoing any edict concerning legislation and taxation, and they claimed the right of making police regulations, even in matters which had no connection with dispensation of justice. On the other hand, their rights were frequently trespassed by the Royal Council, which quashed their decrees and called to its hearing causes which they had heard.

ii) The "Presidiaux", 102 in number, were tribunals of first instance, having final decisions in civil cases up to a certain value and a decision subject to an appeal when this sum is surpassed. They also possessed a certain criminal jurisdiction.

iii) The Courts of the "bailliages" or "sénéchaussés", served for petty causes and for receiving appeals from feudal courts. They were composed of the same members of the "presidiaux", but a smaller number sufficed for judgement.

Beside these ordinary Royal Courts there were other extraordinary commissions, styled "Chambres Ardentes", with special powers and summary procedures, and they dealt with corrupt financiers, smugglers, heretics and other troublesome people.

The Feudal Courts, too, were divided into three classes: high, middle and low courts. They had a double jurisdiction and varying rights of imposing penalties. The gravest criminal offences had been withdrawn from the "high courts" by the Royal Court as "cas royaux", and several cases were taken to Royal Courts for appeal. The number of these courts, as one should expect, was immense. 
Besides these Courts, there were also the Municipal Courts, or town-courts, and the Ecclestiastical Courts.

The final reform of suppressing all Courts did not succeed and feudal and corporative Courts lingered on until the Revolution.

"Such a multitude of tribunals, says Montague, should have ensured cheap and speedy justice. But the entanglement of jurisdictions and the possibility of successive appeals went far to annul this advantage" (10).

"The multiplicity and confusion of tribunals, $f$ ' adds, corresponded to a multiplicity and confusion of law's". In some regions the customary law, in others the written law was in force. In some places the Justinian Code, in others the Theodosian Code was followed. So that at the eve of the Revolution there were in France no less than 360 distinct bodies of law.

The Criminal Law was more uniform and simple, but like the Criminal Law of the surrounding countries, it was still unreasonable, cruel and unfair: the withholding of counsel, the use of torture, the exemption of some classes from certain punishments reveal the truth of this assertion.

But the most outstanding blemish of the French Law was undoubtedly the "lettre de cachet", that is a secret administrative order under the privy seal which deprived a man of his freedom. It is true that such letters were not much used in the years preceeding the Revolution, and that the persons arrested remained confined for a few days and were mildly treated, the practice, however, was an abuse.

\section{1.-RELIGIOUS CAUSES}

\section{A.-The Reformation}

The Reformation was an ecclesiastical revolution - but it threw the seed of the political and social revolution of the XVIII centuly (11).

In spite of opposition, Protestantism made its way into France. In 1.559 there were in that country 72 Reformed Churches, and up to 1561 - that is, two years later-no less than

(10) Montague F.C.: op. cit. p. 49.

(11) Hergenrother: Storia Universale della Chiesa (VI Edir.) Vol. VII. p. 307 . 
2,000. A number of princes and noblemen joined this new sect together with the aitisans and workingmen. Thus it came to pass than in France too, protestantism became a political and military party; and the French Kings, in opposing it, were defending their own interests (12).

The rivalry between the Catholics and the Protestants gave ise to the Wars of Religion. which lasted thirty years. These wars opened up France to the interference of such foreign princes as Elizabeth and the German troopels called in by the Protestants, and Philip IJI of Spain called in by ihe Catholics. During these wars political opinions ianged themselves and this civil disorder threatened the overthrow of the monarchical centralization. With the Treaty of Nantes the liberty of practising their religion in their own homes was accorded to Protestants, all employments were opened to them and mixed tribunals were created; they fur thermore became a political power. being recognized for 8 years as masters of about 100 towns (places de sureté). In the War against the House of Austria, France had the support. of the Lutheian Princes of Germany and of the Protestant countries such as the Sweden of Gustavus Adolphus. Protestantism may be said to have been upheld by France. With the famous "Renversement des Alliances", about the midde of the XVIII century, the traditional strife between France and the Austrian House ended. But France became involved in a war against England and Prussia, a country which was then rapidly rising in importance (13). It was' as a new "Hundred Years War", which however, could not and did not hinder the contact between the English and the French philosophers. Montaigne, Bayle, Evremond were charmed by the new English literature of Hobbes, Tocke, Shaftesbury and Chubb. Bolingbroke lived for a long time in Paris and Evremond in London. Protestantism gave rise to English free-thinking: and English free-thinking to French Illuminism. French Illuminism coincided with Parliamentary Gal. licanism and Jansenism and the three together weakened the idea of Religion, the only bulwark of order, obedience and right. No authority could withstand the increasing arbitrary sovereignty of individual reason.

(12) Goyau George: France (in Cath. Encyc. Vol. VI, p. 170),

(13) Id: op. cit., pp. 171, 172. 


\section{B.-Gallicanism}

Gallicanism is the ensemble of tendencies, practices and, above all, doctrines regarding the constitution and extension of the spiritual power, chiefly spread throughout old France, as an opposition, in different measures, to certain pierogatives of the Pope with regard to the Church, and of the Church with regard to the State (14).

From this definition we gather that there are two sorts of Gillicanism :

a) the Ecclesiastical Gallicanism, aftecting the internal public right of the Church, and

b) the Political Gallicanism. affecting the external public right of the Church.

Bossuet styles these two sorts: (Gallicanism of Bishops and and Gallicanism of Magistrates.

M. Hanotaux (15) adds a third soit:

c) the Royal Gallicanism or the King's Gallicanism.

The Episcopal or Bishops' Gallicanism can be briefly suminarised in the following 4 Articles, formed by the Clergy of France in their Declaration of 1682 :

1. The Pope received fiom God dominion. only over things: spiritual and such as concern salvation : hence Kings and Princes in temporal affairs are subject to no ecclesiastical power;

2. The decrees of the Council of Constance sanctioning the superiority of the Council to the Pope are to be upheld;

3. The exeicise of the papal power is to be moderated by the ecclesiastical canons, and by the customs, rules and constititions within the kingdom; and

4. The decision of the Pope in matters of faith, although the most weighty, is not final without the consent of the Church (16).

These articles were denounced by the Holy See, and canonical institution was refused to any prelate who had signed and approved them. Matters went so far that France seemed on the verge of a schism.

(14) Arquillière H. X.: Gallicanisme (in Dictionnaire de la Foi Catholique, Vol. II, p. 193).

(15) M. Hanotaux: Introduction to "Recueil des Instructions donnecs aux ambassadeurs..." Rome, t. I, Paris 1888.

(16) Arquillière H. X.: l.c. 
The Pailiamentary Gallicanism, divulged by Pithou in his pamplet "Le Libertés de l'Eglise Gallicane", was condemned in 1594. Pithou founds his theory of the rights of the civil power in France upon mixed and ecclesiastical affairs on a negative basis. which. however, screens a positive doctrine. He shows no preoccupation of determining the place of the Pope in the Holy Hierarchy, but he determines what the Pope cannot do in France. Similarly, he does not speals of his infallibility, but he asserts that tis power is bound by the canons accepted in France. His system is neither theological nor philosophical, but juridical. and, following it, the Parliamentarians held that all the external discipline of the Church was, up to a certain limi-, their own task, and that they had the right to limit or to supervise the administration of Bishops and Pope in the Country, to control the deeds of their ministry and teaching, and to substitute them as much as possible in their judicial power. All these claims ended. later on, in the tearing and burning of papal bulls and orders, and reduced to nothing the ecclesiastical jurisdiction within the Church of France. This kind of Gallicanisin became often the most suitable weapon in the hands of the anticlericals (17).

'The Royal or King's Gallicanism, ais Hanotaux remarks, is more of a practice than of a theory. The King availed himself of the Pope's teaching, of the Bishops' doctrines, of ultramontane theologians' views, of juridical systems, to ensure his independence and absolute sway (18).

Imbart de la Tour writes on this subject: "What the King leaves to Rome is the theoretical region of doctrines; what he safeguards are the real and tangible advantages" (19). As a matfer of fact, the Church, in order to safeguard her teaching and fulfil her duty as custodian of the Christian doctrine, in several occasions, had to sacrifice all the rest.

Royal Gallicanism was chiefly based:

a) on the sacred character of the king's person, as if he were the anointed of God,

b) on the services rendered by the French Monarchy to the Church of France (foundation and protection) and to the

(17) Arquillière: 1.c. 195.

(18) Hanotaux : l.c. p. L. sqq.

(19) Imbart de la Tour: Les origines de la Reforme, Paris, 1909. t. II, p. 91 . 
Church in general (establishment of temporary power),

c) on the duty of the Monarchy as sovereign power to safeguard Catholic Faith and to impose the observance of ecclesiastical canons.

It is not our task to explain how this false system was introduced into Fance, but we only say that Louis XIV approached religious affairs with that spirit of gravity that was natural to hirn, but at the same time with the full persuasion of the sacredness and infallibility of his mission. $\mathrm{He}$ is the real personification of Gallicanism, living, militant and victorious.

During this monarch's weak successors the Royal Gallicanism gave way to the Political Gallicanism, especially during the religious struggle between the Faithful and the Jansenists; and this was pushed so much forward, that it became odious and ridiculous $(20)$. Of these quarrels we are yoing to speak.

\section{C.-Jansenism}

With the revival of the old controversy about Grace, there came in the fore the so-called Jansenism. Jansenius, Bishop of Ypres, published in 1640 a book called "Augustinus", which aimed at setting forth and developing the teaching of St. Augustine, particularly about Grace. This book was the source of a hot controversy. It was attacked by some and defended by others.

Pope Urban VIII forbade the reading of this book. and after the author's death, in 1653 , Innocent $X$ condemned 5 propositions extracted from the book, which confained the gist of the teaching of Jansenius, and embraced the chief points of the heresy called after his "Jansenism". The Pope's Bull was well received by the French Court and by the Assembly of the Clergy; but Jansenius' followers kept a "respectful silence"' about this matter, holding that the 5 propositions condemned were not uttered by Jansenius in a heretical sense.

Pope Alexander VII declared in another Bull that the 5 propositions were condemned in the natural sense of the author's words, and renewed the censure upon them. This new censure, was met with a fierce opposition from the Jansenists, who now took the name of Port Royal Society, because of the place where they used to meet. Among the Jansenists there were 4 French

(20) Arquillière: op. cit., pp. 259-262. 
- Bishops and other ecclesiastics. For this reason the Pope, by means of another Bull, required the prompt anthscription to the condemnation from ecclesiastics and religious members of both sexes.

Among those that obstinately resisted this Bull were the nuns of the convent of Port Royal "pure as angels, stubborn as devils."

After Pope Alexander's death, 19 other bishops wrote to his successor Clement IX that they were of the same views of the 4 bishops already mentioned. Such a complication caused the Pope to find a way" for an agreement between the parties: the agreement was come to and it was called by the Jansenists the "Pax" Clementina" or the "Pare Ecclesiae". "(1668).

This truce brought an interval of outward calm, but the chief partisans of the er ror remained unchanged. At the end of the century, the storm was stirred anew by the publication of the Jansenist work written by Quesnel entitled "Reflexions Morales" and by the pamphlet "Cas de Conscience", which caused the promulgation of Clement XI's Bull "Unigenitus" (1713) and the Papal Constitution "Vineam Domini" (1705). The "Vineam Domini" declared that the respectful silence was not sufficient for obedience. This decision was received with submission almost everywhere but at Port Royal, where the nuns showed only a mere external submission. As a punishment, their abbey was dissolved, the nuns were scattered and the buildings themselves were destroyed by order of the Government. The barshness of the punishment caused a sense of popular sympathy towards the nuns, and of odiosity against the Government and the Catholic cause.

The Bull "Unigenitus" censured 101 propositions extracted from the "Reflexions.Morales". Cardinal Noailles, Archbishop of Paris, who had hastily approved and praised the work, did not at once accept the Bull. Although the Bull was universally accepted. there were some of the same views of Noailles, who appealed from the Bull to a General Council : hence their name of "Appellants". In order to settle the matter Louis XIV proposed the convocation of a national council. but this project was not carried out because of the King's illness and death. The Jansenist party became bolder when the Regent to Louis XV appointed Noailles head of the Council "de conscience" : they asked for explanations of the Bull. The Pope stood firm and resolved to decardinalize Noailles. 
A cry for an appeal to a general Council was again heard, a c1y that was adhered to by the Sorbonne and by Noailles. The latter was called in vain to order by Pope and Cardinals. With the Bull "Pastoralis Officil" the Pope separated the dissenters from the communion of the Church. Noailles lodged an appeal to this sentence: he was followed by his Chapter and by the Parliament, whose members became, henceforward, constantly hostile to the Holy See, and put in full force Parliamentary Gallicanism.

A national schism was threatening. Thanks to the Regent, Cardinal de Rohan and Abbè Dubois, Noailles was persuaded to publish, after however a long delay, a note of acceptance of the Bull, which was registered by letter"s patent and the Bull "Unigenitus' became now the law of the State. The victory of the Holy See seemed complete.

But on examining Noailles's papers it was found out that he had prepared two different editions of subscription, of which one. without restrictions of any sort, was presented to the Pope, and another with reservations was to be kept secret. The Jansenists went carrying on their campaign and the Bishop of Senez, Soanen, went so far as to suggest a schism and a revolt, for which suggestion he was suspended and exiled. This sentence was ratified by Pope and King. It, however, raised new incidents among the Jansenist party.

At last Noailles, being now old, showed himself ready to submit and wrote to the Pope to this effect. After 15 years of resistance he unconditionally submitted to the Holy See. Let us give no judgment about the sincerity of this submission! The victory of the Holy See seemed this time to be really decisive. Yet, it was not so (21).

The obstinate Appellants continued to discuss the value of the Bull "Unigenitus", and their heresy had by this time been widely spread and popularised. At the same time, the Parliamentarians. in order to push forward their Gallican views, endorsed Jansenism, and they strove to legislate. if not over the Pope, at least, over the Bishops and the King himself. This parliamentary hostility increased so much, that when, in 1730, the Parlement of Paris was ordered by the King to sign the formulary and the

(21) De Becdelièvre A.: Jansenisme (in Dictionnaire de la Foi Catholiqne, Vol. II. 1153-1192). 
acceptation of the Bull, they would not, asserting the Royal interests and the Gallican Liberties against the Holy See.

They even meddled in scandalous fashion in the administration of the Sacraments and persecuied bishops and priests accused of refusing absolution to those who would not submit to the Holy see, or who would not bear a ceitificate of having made a confession with a priest furnished with regular jurisdiction. The King favoured the orthodox priests and cancelled the judgments passed against them by the Parlements (22). Twice he sent the Parliamentaians in exile. When the latier saw all their hopes shattered, they chose as a target of their attacks the Jesuits, who had been their foremost adversaries in their anti-religious and anticlerical campaign. The same Jansenistic influence was revealed, 20 yeais afterwards. in the planning of the "Civil Constitution of the Clergy" and in the establishment of the Constitutional Church. The sect, however, died in this sterile attempt of schism (23). But they had already gained the support of the sect of the Philosophers or Illuminists, which became, not only the cause of the Jesuits' expulsion from France, but also one of the most influential causes of the French Revolution.

\section{(To be continued)}

\section{ACKNOWLEDGMENT}

We thank the Rev. Rector of St. Edward's College for "Edwardian", Vol. V. No. 2, the inceresting magazine of the College.

(22) Forget J.: Jansenius and Jansenism. (in Catholic Eucyclopedia Vol. VIII, p. 292).

(23) De Becdelièvi'e A.: 1. c., p. 1184. 